\title{
Goat milk fatty acid composition in the Peninsula of Baja California, Mexico
}

\author{
Composición de la grasa láctea de cabras en la Península de Baja \\ California, México
}

\author{
Eduardo Toyes-Vargas, ${ }^{1}$ M.Sc, Miguel Cordoba-Matson, ${ }^{1}$ Ph.D, José Espinoza-Villavicencio, ${ }^{2}$ Ph.D, \\ Alejandro Palacio-Espinosa, ${ }^{2}$ Ph.D, Bernardo Murillo-Amador, ${ }^{1 *}$ Ph.D.
}

${ }^{1}$ Centro de Investigaciones Biológicas del Noroeste, La Paz, Baja California Sur, México. ${ }^{2}$ Universidad Autónoma de Baja California Sur, La Paz, Baja California Sur, México. *Corresponding: bmurillo04@ cibnor.mx

Recibido: Septiembre de 2012; Aceptado: Febrero de 2013.

\begin{abstract}
Objective. The objective of the study was to determine the composition of fatty acids in milk of Creole goats in an extensive production system in an arid region of the peninsula of Baja California and compare it to two seasons of the year (rainy and dry). Materials and methods. Sampling was conducted during the dry season (June) and after the rainy season (December) in the municipality of Comondú in Baja California Sur. The extensive production system used involved releasing goats to roam freely in the rangeland to graze for food, and no additional food or supplements were provided. Results. The most abundant fatty acids were saturated fatty acids (66.3 and $70.9 \%$ in the rainy and dry reasons, respectively). The most abundant of these were palmitic, myristic, and stearic acid in both seasons. Monounsaturated fatty acids (15-20\%) were the most numerous in terms of isomers, but mostly in low concentrations. The largest average constituent of polyunsaturated fatty acids (5$6 \%$ ) was linoleic acid (3\%) and alpha-linolenic acid (1.2\%) in both seasons. Branched, fatty acid concentrations were highly variable; the only stable constituents were $\mathrm{C} 15: 0$ iso (1.5\%) and $\mathrm{C} 16: 0$ anti-iso, with $0.7 \%$ of total fatty acids. Conclusions. The seasons in this extensive production system significantly effected the composition of most monounsaturated and branched fatty acids in goat milk; however, saturated and polyunsaturated showed only a few compositional changes in abundance of fatty acids. Moreover, season effects were not significant on the total fatty acid content, except for branched fatty acids and omega-3.
\end{abstract}

Key words: Chemical composition, goat, milk fatty acids, nutritional quality (Source: SCIRUS). 


\section{RESUMEN}

Objetivo. El objetivo del presente estudio fue determinar en un sistema de producción extensivo la composición de la grasa en leche de cabras Criollas en una zona árida de la península de Baja California en dos épocas del año (lluvias y sequía). Materiales y métodos. Los muestreos se realizaron durante la temporada de sequía (junio) y después de las lluvias (diciembre) en el municipio de Comondú, Baja California Sur. El sistema de producción extensivo se desarrolla en condiciones de pastoreo en donde las cabras andan libremente buscando alimento, suplementos no fueron proporcionados. Resultados. En las dos épocas año mostraron proporciones muy abundantes de los ácidos grasos saturados de 66.3 y $70.9 \%$ durante lluvias y sequía, respectivamente. Los más representativos de estos fueron el ácido palmítico, mirístico y esteárico. Los ácidos grasos monoinsaturados (15-20\%) fueron los más numerosos en cuanto a isómeros, pero en su mayoría en muy bajas concentraciones. Los ácidos grasos ramificados estuvieron en concentraciones muy variables, presentándose de manera estable el C15:0 iso (1.5\%) y C16:0 ante-iso con 0.7\% del total de ácidos grasos. Conclusión. Se concluye que las épocas del año en el sistema de producción extensivo mostraron efecto significativo en la composición de la mayoría de los ácidos grasos monoinsaturados y ramificados en la leche de cabra; sin embargo, los ácidos grasos saturados y poliinsaturados mostraron pocos cambios en abundancia y composición de ácidos grasos. Además, los efectos de épocas año no fueron significativos en el contenido de ácidos grasos totales, con excepción de ácidos grasos ramificados y omega-3.

Palabras clave: cabras, calidad nutricional, composición química, grasa láctea (Fuente: SCIRUS).

\section{INTRODUCTION}

In many developing countries the production of goat milk has become a useful strategy to address malnutrition, especially among children (1). In arid areas, there is especially growing interest in raising goats because of their excellent adaptability to severe climatic temperatures and because their milk and derived products such as cheeses are considered of good nutritional quality (2). This, plus the need to feed a growing number of people in marginal, arid and disadvantaged areas has contributed to the emergence of many small farms dedicated to goat milk production, especially in places such as Africa, Asia, the Mediterranean and Latin America (2), as well as in arid zones of the peninsula of Baja California.

Recently, the nutritional guidelines for humans stress the importance of maintaining a balanced diet to help reduce the incidence of noncommunicable diseases, such as obesity, type- 2 diabetes, cancer, and cardiovascular diseases (3). From this viewpoint, the lipid fraction of milk is a particularly important in human diet, associated with numerous benefits, since it is a rich source of bioactive lipids (4). It is recommended that total fat, saturated fatty acids, polyunsaturated, $n-3$ and $\mathrm{n}-6$, and trans-fatty acids should contribute $<0.15$ to $0.30,<0.10,<0.05-0.08,<0.01$ to 0.02 and $<0.01$ of the total human energy intake, respectively (5).

Since the quality of diet affects the chemical composition of milk fat of other ruminants, such as cows, the purpose of this study was to determine the composition of milk fat of goats in a traditional extensive production system during two seasons in an arid region of the Baja California Peninsula.

\section{MATERIALS AND METHODS}

Study area. The study was conducted in the municipality of Comondú, Baja California Sur, Mexico. The site is located in the small community called Jesus Maria $\left(25^{\circ} 19^{\prime} 51^{\prime \prime} \mathrm{N}\right.$, $111^{\circ} 25^{\prime} 44^{\prime \prime} \mathrm{W}$ ) at $160 \mathrm{~m}$ above sea level, with annual rainfall of $180 \mathrm{~mm}$, average temperature of $18.7^{\circ} \mathrm{C}$ during the wet season and $22.1^{\circ} \mathrm{C}$ during the dry season (6).

Dry and wet season. The dry season begins in February and ends in June; the rainy season begins in July and ends in September.

Extensive system. In this production system, goats are manually milked during the morning and then released onto rangeland, where they search for water and food, which consists mostly of leaves and fruits of native plants. In the afternoon, the animals return to the ranch. In the rangeland, the goats consume many plant species, depending on the season when legume and non-legume species are available. Only one farmer using this system was included in the study.

Consumed and sampled species. The legumes species consumed by the goats include Pithecellobium confine Standl, Prosopis palmeri 
S. Wats., Acacia farnesiana (L.) Willd., Acacia brandegeana, Acacia peninsularis (Britt. and Rose) Standley, Cercidium $X$ sonorae Rose and Johnston, Lysiloma candida Brandegee, Cercidium microphyllum (Torr.) Rose and Johnston, Cercidum floridum Benth. Ex A. Gray subsp. Peninsulare (Rose) Carter. Non-legumes species include Lippia palmeri L., Bursera microphyla Gray, Jatropha cuneata Wiggins and Rollins, Fouquieria diguetii (Van Tieghem) I. M. Jhtn., Lycium brevipes Benth., Celtis reticulata Torr., Ruellia californica (Rose) I. M. Jhtn., Ferocactus spp., Phrygilanthus sonorae S. Watson, Jatropha cinerea (C.G. Ortega) Muell. Arg. In D.C., Opuntia cholla Weber, Pachycereus pringlei (S. Wats) Brit. \& Rose, and Stenocereus thurberi (Engelm.) Buxbaum.

Animals and sampling. Ten native goats (Creole) mating with indefinite Anglo-Nubia goats were selected at random per trip to the farm and were sampled for milk. This was repeated twice per season, for a total of 20 goat milk samples per season (dry and rainy season). The samples of goat milk obtained were from animals that had given birth two to five times (lactations) and had been lactating over 60 days. The samples were obtained by hand milking. Udder was cleaned prior to milking to avoid contamination by dirt or feces. A total of $25 \mathrm{ml}$ were obtained per sampled animal, and the milk was collected in sterile Falcon tubes, sealed, and labeled at once. These were kept on ice until arrival at the laboratory.

Lipid extraction. The milk lipids were extracted using the method established by Bligh and Dyer (7), where $30 \mathrm{mg}$ of a lyophilized sample was placed in a test tube and a mixture of $\mathrm{CH}_{3} \mathrm{OH}: \mathrm{CHCl}_{3}: \mathrm{H}_{2} \mathrm{O}(1: 2: 0.5)$ was left to stand for $24 \mathrm{~h}$ without light to facilitate complete removal of lipids.

This mixture was then sonicated three times, and $1 \mathrm{ml}$ of $\mathrm{CH}_{3} \mathrm{OH}$ with $2 \mathrm{ml}$ of distilled water was added. This was centrifuged at $2,250 \times \mathrm{g}$ (3700 $\mathrm{rpm}$ ) for $15 \mathrm{~min}$. After centrifugation, the fraction of lipid- $\mathrm{CH}_{3} \mathrm{OH}$ was removed with a Pasteur pipette and emptied into a tube. The process was repeated. The centrifuged extract was used to make two determinations: quantification of total lipids and acid derivatization.

Quantification of total lipids. The method of Marsh and Weinstein (8) was used to quantify total lipids. A portion of the lipid- $\mathrm{CH}_{3} \mathrm{OH}$ fraction was evaporated to dryness with nitrogen gas; to this, $2 \mathrm{ml}$ of concentrated $\mathrm{H}_{2} \mathrm{SO}_{4}$ was added; the tube was sealed with aluminum foil and closed with a lid to prevent contamination. Subsequently, this was calcinated in an oven at
$200 \pm 2{ }^{\circ} \mathrm{C}$ for $15 \mathrm{~min}$, and allowed to stand for 5 min to reach room temperature. Then the tubes were placed in an ice water bath for $5 \mathrm{~min}$. Once cooled, $3 \mathrm{ml}$ distilled water was added to the mixture and vortex mixer. The resulting mixture was placed in a quartz cell and the absorbance was read in a spectrophotometer at $375 \mathrm{~nm}$. Control samples for calibration contained only $\mathrm{H}_{2} \mathrm{SO}_{4}$ and received the same treatment as the samples.

Acid derivatization. The remaining fraction of the lipid- $\mathrm{CH}_{3} \mathrm{OH}$ was dried with liquid nitrogen and then $2.5 \mathrm{ml}$ of a solution of $\mathrm{HCl}-\mathrm{CH}_{3} \mathrm{OH}$ $(5 \%, v / v)$ was added. This mixture was placed in a water bath for $2.5 \mathrm{~h}$ at $85^{\circ} \mathrm{C}$. The methyl esters obtained from the reaction were extracted with $1.5 \mathrm{ml}$ of hexane using Pasteur pipettes. Subsequently, the total volume of hexane was evaporated to dryness and recovered with liquid nitrogen and re-suspended in $250 \mu$ of hexane and placed in a vial sealed with Teflon and injected into the gas chromatograph.

\section{Identification and quantification of fatty} acids. For determining the concentration of fatty acids, a gas chromatograph coupled to a mass spectrometer (c/quadrupole Varian CP38001200) was used, equipped with an injection port and a OmegaWax ${ }^{\mathrm{TM}} 250$ capillary column $30 \mathrm{~m}$ in length of fused polyethyleneglycol silica, with i.d. of $0.25 \mathrm{~mm}$ and $0.25 \mu \mathrm{m}$ film thickness, at a flow rate of $1.2 \mathrm{ml} / \mathrm{min}$ and high purity helium as the carrier gas.

The fatty acids in the samples were identified by comparing their mass spectra calculated with the program Wsearch 32 ver. 1.6 and comparing of retention times in the sample peaks with retention times of 37 standard, commercially available methyl fatty acid esters. To calculate the concentration of the fatty acids present in the samples, the peak area was integrated and interpolated with a calibration curve of five known concentrations $(5,10,20,40$, and $80 \mu \mathrm{g} / \mathrm{ml})$ of each of the 37 standards methyl esterified fatty acids with respective area under the peaks directly proportional to the mass.

Statistical analysis. Data was analyzed with Statistica 10.0 using univariate analysis of variance (ANOVA) of one way of classification, taking into account seasons as the main study factor for a completely randomized design. Bartlett's Box-test was used to test the homogeneity of variance. In all cases, differences of means were tested using t-Student test. A p-values of $<0.05$ was considered as statistically significant. 


\section{RESULTS}

Types of fatty acids. Table 1 shows that in this production system branched fatty acids and omega-3 fatty acids had significantly higher concentrations during the rainy season $(p \leq 0.01)$.

Table 1. Concentration of types of fatty acids in the milk of Creole goats in an extensive production system.

\begin{tabular}{|c|c|c|c|}
\hline \multirow[b]{2}{*}{ Fatty acids } & \multicolumn{2}{|c|}{ Season } & \multirow[b]{2}{*}{ Significance } \\
\hline & $\begin{array}{c}\text { Rainy } \\
(\mu \mathrm{g} / \mathrm{mg})\end{array}$ & Dry $(\mu \mathrm{g} / \mathrm{mg})$ & \\
\hline saturated & 771.9 & 718.7 & NS \\
\hline monounsaturated & 195.39 & 166.78 & NS \\
\hline polyunsaturated & 62.44 & 49.62 & NS \\
\hline branching & $66.86^{a}$ & $27.71^{b}$ & $* *$ \\
\hline omega-3 & $27.29^{a}$ & $17.12^{b}$ & $* *$ \\
\hline omega- 6 & 40.37 & 32.74 & NS \\
\hline $\begin{array}{l}\text { omega-3/ } \\
\text { omega- } 6 \text { ratio }\end{array}$ & 0.55 & 0.52 & NS \\
\hline
\end{tabular}

Saturated fatty acid analysis. Table 2 shows that the concentration of stearic acid (C18:0), heptadecanoic (C17:0) and heneicosanoic $(\mathrm{C} 21: 0)$ were more abundant during the rainy season $(p \leq 0.05)$.

Table 2. Saturated fatty acid concentration in the milk of Creole goats in an extensive production system.

\begin{tabular}{cccc}
\hline & \multicolumn{2}{c}{ Season } & \\
\cline { 2 - 3 } Fatty acids & $\begin{array}{c}\text { Rainy } \\
(\boldsymbol{\mu} \mathbf{g} / \mathbf{m g})\end{array}$ & $\begin{array}{c}\text { Dry } \\
(\boldsymbol{\mu} \mathbf{g} / \mathbf{m g})\end{array}$ & Significance \\
\hline C12:0 & 63.93 & 60.89 & NS \\
C13:0 & 2.17 & 2.14 & NS \\
C14:0 & 165.66 & 149.43 & NS \\
C15:0 & 30.74 & 18.96 & NS \\
C16:0 & 366.10 & 351.90 & NS \\
C17:0 & $18.94 \mathbf{a}$ & 11.33 b & $*$ \\
C18:0 & 136.50 a & 72.70 b & $*$ \\
C19:0 & 3.04 & 2.15 & NS \\
C20:0 & 14.59 & 7.97 & NS \\
C21:0 & $2.16 \mathrm{a}$ & $1.20 \mathrm{~b}$ & $*$ \\
C22:0 & 4.11 & 2.88 & NS \\
C23:0 & 2.68 & 1.85 & NS \\
\hline
\end{tabular}

NS $p>0.05 ; * p \leq 0.05, * * p \leq 0.01$ Averages with different letter in rows are statistically different ( $\mathrm{t}$-Student $\mathrm{p}=0.05$ ).

Monounsaturated fatty acids. Significant differences were found $(p \leq 0.05)$ in acids $C 16: 1$ $\mathrm{n}-5$, C17:1 n-3, C19: 1, and C20:1 n-9, but acids $C 16: 1 n-1,20: 1 n-3$, and various isomers of $18: 1(n-3, n-5, n-6$, and $n-7)$ showed even higher significant differences $(p \leq 0.01)$. In all cases, they were more abundant during the rainy season (Table 3 ).
Table 3. Monounsaturated fatty acid concentration in the milk of Creole goats in an extensive production system.

\begin{tabular}{|c|c|c|c|}
\hline \multirow[b]{2}{*}{ Fatty acids } & \multicolumn{2}{|c|}{ Season } & \multirow[b]{2}{*}{ Significance } \\
\hline & Rainy $(\mu \mathrm{g} / \mathrm{mg})$ & $\begin{array}{c}\text { Dry } \\
(\mu \mathrm{g} / \mathrm{mg})\end{array}$ & \\
\hline$C 14: 1 n-5$ & 2.40 & 1.86 & NS \\
\hline C14:1 n-7 & 0.36 & 0.36 & NS \\
\hline C15:1 n-7 & 2.12 & 1.99 & NS \\
\hline $\mathrm{C} 16: 1 \mathrm{n}-1$ & $0.68^{a}$ & $0.40^{b}$ & $* *$ \\
\hline $\mathrm{C} 16: 1 \mathrm{n}-3$ & 0.92 & 0.62 & NS \\
\hline C16:1 n-5 & $1.45^{\mathrm{a}}$ & $0.96^{b}$ & * \\
\hline C16:1 n-7 & 12.29 & 9.31 & NS \\
\hline $\mathrm{C} 16: 1 \mathrm{n}-9$ & 5.10 & 3.89 & NS \\
\hline $\mathrm{C} 17: 1 \mathrm{n}-3$ & $10.02^{a}$ & $5.86^{b}$ & $*$ \\
\hline$C 17: 1 \mathrm{n}-5$ & 0.61 & 0.37 & NS \\
\hline $\mathrm{C} 18: 1 \mathrm{n}-3$ & $6.16^{\mathrm{a}}$ & $2.90^{\mathrm{b}}$ & $* *$ \\
\hline C18:1 n-5 & $2.49^{a}$ & $0.68^{b}$ & $* *$ \\
\hline $\mathrm{C} 18: 1 \mathrm{n}-6$ & $7.10^{\mathrm{a}}$ & $2.01^{b}$ & $* *$ \\
\hline$C 18: 1 \mathrm{n}-7$ & $2.07^{a}$ & $0.41^{b}$ & $* *$ \\
\hline $\mathrm{C} 18: 1 \mathrm{n}-9$ & 135.03 & 110.03 & NS \\
\hline $\mathrm{C} 18: 1$ trans & 9.52 & 7.09 & NS \\
\hline C19:1 & $2.84^{a}$ & $1.27^{\mathrm{b}}$ & $*$ \\
\hline $\mathrm{C} 20: 1 \mathrm{n}-11$ & 2.58 & 1.68 & NS \\
\hline $\mathrm{C} 20: 1 \mathrm{n}-3$ & $1.21 \mathrm{a}$ & $0.33^{b}$ & $* *$ \\
\hline $\mathrm{C} 20: 1 \mathrm{n}-9$ & $3.14^{\mathrm{a}}$ & $0.98^{b}$ & * \\
\hline $\mathrm{C} 22: 1 \mathrm{n}-9$ & 0.21 & 0.03 & NS \\
\hline $\mathrm{C} 24: 1 \mathrm{n}-9$ & 2.64 & 1.77 & NS \\
\hline
\end{tabular}

NS $p>0.05 ; * p \leq 0.05, * * p \leq 0.01$ Averages with different letter in rows are statistically different ( $\mathrm{t}$-Student $\mathrm{p}=0.05$ ).

Polyunsaturated fatty acids. Table 4 shows that eicosatrienoic acid (C20:3 n-3) and 19:2 $(p \leq 0.05)$ and linolenic acid $\mathrm{C} 18: 3 \mathrm{n}-3$ cis $(p \leq 0.01)$ had significant higher concentrations during the rainy season.

Table 4. Polyunsaturated fatty acids concentration in the milk of Creole goats in an extensive production system.

\begin{tabular}{cccc}
\hline \multirow{2}{*}{ Fatty acids } & \multicolumn{2}{c}{ Season } & Significance \\
\cline { 2 - 3 } & $\begin{array}{c}\text { Rainy } \\
(\boldsymbol{\mu} \mathbf{g} / \mathbf{m g})\end{array}$ & $\begin{array}{c}\text { Dry } \\
(\boldsymbol{\mu} \mathbf{g} / \mathbf{m g})\end{array}$ & NS \\
\hline C18:2 n-5 & 0.84 & 0.61 & NS \\
C18:2 n-6 cis & 29.83 & 26.12 & NS \\
C18:2 n-6 trans & 0.77 & 0.63 & $* *$ \\
C18:3 n-3 cis & $18.58^{\mathbf{a}}$ & $9.17^{\mathrm{b}}$ & NS \\
C18:3 n-3 trans & 0.52 & 0.41 & NS \\
C18:3 n-6 & 0.58 & 0.41 & $*$ \\
C19:2 & 3.67 a & 2.50 b & $*$ \\
C20:3 n-3 & 0.40 a & 0.20 b & NS \\
C20:3 n-6 & 2.45 & 1.84 & NS \\
C20:4 n-6 & 2.45 & 1.84 & NS \\
C20:5 n-3 & 1.73 & 1.63 & NS \\
C22:5 n-3 & 2.78 & 2.68 & NS \\
C22:6 n-3 & 1.34 & 0.96 & \\
\hline
\end{tabular}

NS $p>0.05 ; * p \leq 0.05, * * p \leq 0.01$. Averages with different letter in rows are statistically different ( $\mathrm{t}$-Student $\mathrm{p}=0.05$ ). 
Branched fatty acids. Fatty acids iso $\mathrm{C} 13: 0$, C14:0, C15:0, and C17: anti-iso C14:0, 16:0 and $17: 0$ showed significant differences $(p \leq 0.01)$ as well as $\mathrm{C} 16: 0$ anti-iso $(\mathrm{p} \leq 0.05)$ between seasons, also for all the branched fatty acids. The highest concentrations occurred during the rainy season, although in some cases, they were not statistically significant (Table 5).

Table 5. Branched fatty acid concentration in the milk of Creole goats in an extensive production system.

\begin{tabular}{|c|c|c|c|}
\hline \multirow[b]{2}{*}{ Fatty acids } & \multicolumn{2}{|c|}{ Season } & \multirow[b]{2}{*}{ Significance } \\
\hline & $\begin{array}{c}\text { Rainy } \\
(\mu \mathrm{g} / \mathrm{mg})\end{array}$ & $\begin{array}{c}\text { Dry } \\
(\mu \mathrm{g} / \mathrm{mg})\end{array}$ & \\
\hline $\mathrm{C} 12: 0$ iso & 2.18 & 1.57 & NS \\
\hline $\mathrm{C} 13: 0$ iso & $4.90^{a}$ & $1.53^{\mathrm{b}}$ & $* *$ \\
\hline $\mathrm{C} 14: 0$ iso & $5.76^{a}$ & $1.89^{\mathrm{b}}$ & $* *$ \\
\hline C14:0 anti-iso & $11.06^{a}$ & $4.88^{b}$ & $* *$ \\
\hline $\mathrm{C} 15: 0$ iso & $23.90^{a}$ & 7.72 b & $* *$ \\
\hline C15:0 anti-iso & 0.98 & 0.53 & NS \\
\hline $\mathrm{C} 16: 0$ iso & $6.13^{a}$ & $3.63^{b}$ & * \\
\hline C16:0 anti-iso & $9.33^{a}$ & $4.79^{b}$ & $* *$ \\
\hline $\mathrm{C} 17: 0$ iso & 2.20 a & $0.99 \mathrm{~b}$ & $* *$ \\
\hline C17:0 anti-iso & $0.43^{a}$ & $0.18^{b}$ & $* *$ \\
\hline C18:0 iso & 0.63 & 0.61 & NS \\
\hline
\end{tabular}

\section{DISCUSSION}

Effect of seasons on the concentration of types of fatty acids in goat milk. Of the major components of milk fat, i.e. by their classification according to the type of fatty acid, the results are similar to those reported by Lock and Shingfield (9) and Moate et al (10), where they report that the milk fat of ruminants typically contains a higher proportion of saturated fatty acids, $70-75 \%$, largely as a result of rumen microbial bio-hydrogenation, than of monounsaturated $(20-25 \%)$, and polyunsaturated (5\%) fatty acids.

The proportion of saturated fatty acids as a percentage of total fatty acid content was $66.3-70.9 \%$ in this farming system. Differences related to season were not significant. For monounsaturated fatty acids, the goats produced $16.7-16.4 \%$ of total fatty acids. Polyunsaturated fatty acids were present at 5.3-4.9\% of the total, slightly more abundant during the rainy season.

The branched fatty acid concentrations are related to the abundance of rumen bacterial populations, which vary according to the concentration of forage in the diet (11), but also requires the fermentation of amino acids, such as valine, leucine, and isoleucine to give rise to precursors (isobutyrate, isovalerate, or 2-methylbutyrate) of these fatty acids for use in de novo synthesis in mammary glands (12).
The higher proportions of $n-3$ fatty acids in relation to the $n-6$ can be explained by the degree of bio-hydrogenation of the main sources of each of these types of omegas (13). Linoleic acid, which is an n-6 fatty acid, is bio-hydrogenated to a lesser degree (70-90\%) than alpha-linolenic acid $(85-95 \%)$, which is the main source of $\mathrm{n}-3$ in ruminants, which may determine the differences in this ratio. Furthermore, differences in the concentrations of $n-3$ fatty acids between seasons (more abundant during the rainy season), can be explained because green fodder during or just after the rainy season contain higher concentrations of alpha-linolenic acid (14), an important source of n-3 fatty acids in ruminants.

The low variation found in the major components of the fat, i.e., different classifications of fatty acids between sampling times, probably result from practices, as suggested by MartinezCastro et al (15), where feeding programs, management, and climate variations are relatively uniform within each region, which in turn, reduces variations in the composition of milk fat.

In another view, Pinto et al (16) noted that variations in the fatty acid composition of milk fat of cattle are the result of production systems, the lactation period, seasonal variation, and geographical area, but also is influenced by the degree of mastitis that occurs repeatedly in the extensive farming system, since animals are more prone to this condition during foraging. Since health management is rare, another aspect mentioned by Pinto et al (16), is that the breed can have an effect on quality of milk, but in this case, it would be too complex to quantify, since animals sampled were of Creole origin and the vast majority of them have an unknown genetic origin, probably crossed with Anglo-Nubia breeds.

Effects of seasons on saturated fatty acids. Saturated fatty acids, such as medium chain C12:0, C14:0, C16:0, and C18:0, representing most of this type in milk fat, partly agrees with reports by others (17). In our study, concentrations of $\mathrm{C} 16: 0$ and $\mathrm{C} 14: 0$ were most common. This is important because they are the essential ingredients of milk fat, contributing significantly to the physical structure of fat. C18:0 occurred in higher quantities than $\mathrm{C} 12: 0$ $(9.8 \%$ vs. $8 \%)$. This may result from higher unsaturated $\mathrm{C} 18$ fatty acid intake, which is more abundant in the diet, since C12:0 is more abundant in less common feeds, such as coconut oil and laurel than from de novo synthesis (18). 
Effect of seasons on monounsaturated fatty acids. Results of this study was very similar to Chilliard et al (19), where they report that oleic acid is the most prominent monounsaturated fatty acid, with concentrations of $15-21 \%$. In both seasons, monounsaturated fatty acids (15-20\%) were the most numerous in terms of isomers, but mostly in low concentrations. The most abundant was oleic acids at $12 \%$ of total fatty acids. Also, significant differences were found in many isomers that were related to the seasons. This is similar to results by DelgadilloPuga et al (20) who found effects of seasonal variation (summer and winter) of two feeding strategies. The first was of goats grazing in a semiarid rangeland and the second of goats feeding on hay (alfalfa) and grain concentrate. They found that seasonal variation affected the fat content of cheese made from the goat milk, including the most abundant monounsaturated fatty acid, C18:1, which coincides with our findings, with significant differences in the concentration of many isomers of $\mathrm{C} 18: 1$.

Effect of seasons on polyunsaturated fatty acids. In both seasons, of the polyunsaturated fatty acids $(5-6 \%)$, the most abundant fatty acid was linoleic acid (C18:2 n-6 cis) with concentrations $\sim 3 \%$ and alpha-linolenic acid (C18:3 n-3 cis) $\sim 1.2 \%$. These results coincide with reports by others (19). Of the two fatty acids (linoleic acid and alpha-linolenic acid), a seasonal variation was only significant for alphalinolenic acid. Significant seasonal differences were also found for C19:2 and C20:3n-3, but concentrations were small.

\section{Effect of seasons on production of branched} fatty acids. The extensive grazing system showed significant differences on a seasonal basis on the total concentrations of some of the branched fatty acids. Diedrich and Henschel (21) report that, although such fatty acids are found only in trace concentrations in plants independent of seasons, but is found in milk and goat adipose tissue suggesting that microorganisms may be performing symbiotic fermentation (22), suggesting a possible seasonal impact in the presence and distribution of different microorganisms.

We identified 11 different types of branched fatty acids with chain length between 12 and 18 carbon atoms as 7 iso and 5 anti-iso isomers. The results of this study confirm the conclusions of Massart-Leen et al (23) in that only compounds with more than 11 carbon atoms were found.
Our results agree with Vlaeminck et al (11) who report that the most abundant branched fatty acids have 15 atoms in the carbon chain. We found that the $\mathrm{C} 15: 0$ was the most abundant iso (between $1-2 \%$ of total fatty acids). The anti isomers showed no consistent trend and are similar to results obtained by others. (24). In contrast, Cranix et al (25) report that fatty acid $\mathrm{C} 17: 0$ iso was the most abundant, a result contrary to our results.

The broad-spectrum conclusion is that the quality of fatty acids in goat milk in this extensive grazing system is seasonally dependent for many monounsaturated and branched fatty acid constituents, but less so for saturated and polyunsaturated fatty acids. The above statement is supported by the fact that in this extensive production system, the quality of fatty acids in all principal categories (saturated, monounsaturated, polyunsaturated, branched) showed significant differences in compositional abundance in some or many of fatty acids due to seasons. These seasonal differences of milk quality are likely a result of seasonal forage composition changes and/or availability due to seasonal climate changes in the rangeland. These differences may be caused by variation in solar radiation, moisture content, temperature or other seasonal factors affecting the compositional quality of the forage or the availability of certain plant species. Other possible causes, in the change of milk fatty acid quality could be seasonal variation of symbiotic microorganisms, or even changes in goat metabolism related to the extreme contrasts in seasons. Further studies are needed to clarify these differences.

\section{Acknowledgements}

This research was funded in part of the "Composición de la grasa de la leche en diferentes razas de vacas y cabras gestionada bajo diferentes sistemas de alimentación" project, with funding provided by CONACYT program. Some project resources were provided by Centro de Investigaciones Biológicas del Noroeste (CIBNOR) under its program of alternative crops for arid and semi-arid regions. The authors greatly appreciate the technical assistance of Pedro Luna Garcia, Sonia Rocha Guadalupe Meza, and Dolores Rondero Astorga of CIBNOR. Ira Fogel provided editorial services. 


\section{REFERENCES}

1. Ortega-Pérez R, Murillo-Amador B, EspinozaVillavicencio, JL, Palacios-Espinosa A, Carreón-Palau L, Palacios-Mechetnov E, et al. Composición química y concentración de precursores de ácido ruménico y vaccénico en forrajes alternativos para la alimentación de rumiantes en ecosistemas áridos. Trop Subtrop Agroeco 2010; 13:33-45.

2. Haenlein GFW. Goat milk in human nutrition. Small Ruminant Res 2004; 51:155-163.

3. Jacobs MN, Covaci A, Gherghe A, Schepen P. Time trend investigation of PCBs, PBDEs and organochlorine pesticides in selected n-3 polyunsaturated fatty acid rich dietary fish oil and vegetable oil supplements; nutritional relevance for human essential n-3 fatty acid requirements. J Agric Food Chem 2004; 52:1780-1788.

4. Martínez A. Influencia de la nutrición sobre el contenido y tipo de ácidos grasos en la carne de los rumiantes. Arch Zootec 2007; 56:45-66.

5. FAO/WHO. Diet, nutrition and the prevention of chronic diseases. Report of a Joint FAO/OMS Expert Consultation. WHO Technical Report Series; 2003.

6. Instituto Nacional de Estadistica y Geografia (INEGI) Sistemas Nacionales Estadísticos y de Información Geográfica. Mexico: INEGI; 2006. URL Disponible en: www.inegi.com.mx

7. Bligh EG, Dyer WJ. A rapid method of total lipid extraction and purification. Can J Biochem Physiol 1959; 37:911-917.

8. Marsh JB, Weinstein DB Simple charring method for determination of lipids. J Lipid Res 1966; 1:574-576.

9. Lock $A L$, Shingfield KJ. Optimising milk composition. In: Kebreab E, Mills J, Beever $\mathrm{DE}$, editors. Dairying using science to meet consumers needs. Loughborough, United Kingdom: Editorial Nottingham University Press; 2004.

10. Moate $\mathrm{P}$, Chalupa W, Boston RC, Lean IJ. Milk fatty acids. I. Variation in the concentration of individual fatty acids in bovine milk. J Dairy Sci 2007; 90:4730-4739.
11. Vlaeminck $B$, Fievez $V$, Tamminga $S$, Dewhurst RJ, Van Vuuren A, De Brabander D, Demeyer D. Milk odd and branched chain fatty acids in relation to the rumen fermentation pattern. J Dairy Sci 2006; 89:3954-3964.

12. Jenkins TC. Lipid metabolism in the rumen. J Dairy Sci 1993; 76:3851-3863.

13. Loor JJ, Ueda K, Ferlay A, Chilliard Y, Doreau M. Biohydrogenation, duodenal flow, and intestinal digestibility of trans fatty acid and conjugated linoleic acids in response to dietary forage: concentrate ratio and linseed oil in dairy cows. J Dairy Sci 2004; 87:2472-2485.

14. Elgersma A, Ellen G, Dekker PR, Van der Horst $H$, Boer $H$, Tamminga $S$. Effects of perennial ryegrass (Lolium perenne) cultivars with different linolenic acid contents on milk fatty acid composition. Asp Appl Biol 2003; 70:107-114.

15. Martínez-Castro I, Juárez M, Martin-Álvarez J. The composition of fatty acids of milk fat in Spain. Milchwissenschaft. 1979; 34:207-210.

16. Pinto M, Rubillar A, Carrasco E, An-Hen KS, Brito C, Molina L. Efecto estacional y del área geográfica en la composición de ácidos grasos en la leche de bovinos. Agro Sur 2002; 30:75-90.

17. Eastridge M, Qiu X. Conjugated linoleic acid in milk from cows on pasture. Department of Animal Sciences. Ohio State University. Agricultural Research and Development Center. Ohio, United States: 2001.

18. Freund, G. (Ed.). Goat milk quality, raw material for cheesemaking. Surgéres, France: Institut Technique des Produits Laitiers Caprins; 2001.

19. Chilliard Y, Rouel J, Ferlay A, Bernard L, Gaborit P, Raynal- Ljutovac K, Lauret A. Effects of type of forage and lipid supplementation on goat milk fatty acids and sensorial properties of cheeses. Future of the sheep and goat dairy sectors. Zaragoza, Spain: Special issue of the International Dairy Federation; 2005. 
20. Delgadillo-Puga C, Cuchillo-Hilario M, Perez-Gil F. Effect of feeding management and seasonal variation on fatty acid composition of Mexican soft raw goats milk cheese. Ital J Anim Sci 2009; 8:402-404.

21. Diedrich M, Henschel KP. The natural occurrence of unusual fatty acids. 1 . Odd numbered fatty acids. Nahrung 1990; 34:935-943.

22. Rojas A, Lopezbote C, Rota A, Martin L, Rodriguez PL, Tovar JJ. Fatty acid composition of Verata goat kids fed either goat milk or commercial milk replacer. Small Rumin Res $1994 ; 14: 61-66$.

23. Massart-Leën AM, De Pooter $H$, Decloedt $M$, Schamp N. Composition and variability of the branched chain fatty acid fraction in the milk of goats and cows. Lipids 1981; 16:286-292.
24. Shingfield KJ, Reynolds CK, Lupoli B, Toivonen V, Yurawecz MP, Delmonte $P$, Griinari JM, Grandison AS, Beever DE. Effect of forage type and proportion of concentrate in the diet on milk fatty acid composition in cows given sunflower and fish oil. Anim Sci 2005; 80:225-238.

25. Cranix $M$, Steen $A$, Van Laar $H$, Van Nespen $T$, Martin-Teroso J, De Baets B, Fievez V. Effect of lactation stage on the odd and branched chain milk fatty acids of dairy cattle under grazing and indoor conditions. J Dairy Sci 2008; 91:2662-2677. 